\title{
Biomimetic Polymer-Based Engineered Scaffolds for Improved Stem Cell Function
}

\author{
Dinesh K. Patel ${ }^{1}$ and Ki-Taek Lim ${ }^{2, *}$ (]) \\ 1 The Institute of Forest Science, Kangwon National University, Chuncheon-24341, Korea; \\ dineshbhud10@gmail.com \\ 2 Department of Biosystems Engineering, College of Agriculture and Life Sciences, Kangwon \\ National University, Chuncheon-24341, Korea \\ * Correspondence: ktlim@kangwon.ac.kr
}

Received: 14 August 2019; Accepted: 9 September 2019; Published: 11 September 2019

\begin{abstract}
Scaffolds are considered promising materials for tissue engineering applications due to their unique physiochemical properties. The high porosity and adequate mechanical properties of the scaffolds facilitate greater cell adhesion, proliferation, and differentiation. Stem cells are frequently applied in tissue engineering applications due to their excellent potential. It has been noted that cell functions are profoundly affected by the nature of the extracellular matrix (ECM). Naturally derived ECM contains the bioactive motif that also influences the immune response of the organism. The properties of polymer scaffolds mean they can resemble the native ECM and can regulate cellular responses. Various techniques such as electrospinning and 3D printing, among others, are frequently used to fabricate polymer scaffolds, and their cellular responses are different with each technique. Furthermore, enhanced cell viability, as well as the differentiation ability of stem cells on the surface of scaffolds, opens a fascinating approach to the formation of ECM-like environments for tissue engineering applications.
\end{abstract}

Keywords: scaffolds; extracellular matrices; cell functions; stem cells; tissue engineering

\section{Introduction}

Stem cells have received a great amount of attention from academia as well as industry for tissue engineering and regenerative medicine applications due to their exclusive differentiation potential and pluripotency [1-4]. Pluripotent stem cells (PSCs) have the ability to self-renew and they can generate all the types of cell in the body. Embryonic stem cells (ESCs) and induced pluripotent stem cells (iPSCs) are the types of PSCs which are utilized in the field of tissue engineering. The potential of these types of stem cells is governed by their surrounding microenvironments [5]. Several factors such as hormones, growth factors, chemical moieties, and the extracellular matrix (ECM) conditions have wide influence on the differentiation and pluripotency of stem cells [6-11]. Figure 1 represents the different interactions of stem cells with their surrounding microenvironments, which determine their fate [5].

The ECM provides the required physical, chemical, and mechanical support to the cells for better growth and differentiation [12]. The interactions between ECM and cells are extremely affected by the surface morphology of the ECM [13]. These materials have drawn a significant amount of interest regarding cellular activities owing to their similarity in intrinsic morphology with native ECM [14]. Notably, better cell proliferation and differentiation were observed on the surface of scaffolds due to their porosity and adequate mechanical properties which facilitate the easy transport of gases, nutrients, and other regulatory factors [15]. The chemical composition, surface chemistry, porosity, degradation behavior, and mechanical strength of an ECM play very important roles in determining stem cell fate [16]. These materials can be biological or synthetic and degradable or 
nondegradable in nature [17]. The biological scaffolds are derived from living sources, such as human and animal tissues, whereas synthetic scaffolds are prepared from various biocompatible polymers [18]. It is well known that for tissue engineering applications, materials should be biocompatible and biodegradable in nature. Additionally, materials should also have adequate mechanical strength to support cellular activities [19]. The synthetic biodegradable polymer scaffolds have an additional benefit over nondegradable materials - they do not require extra attention to be removed from the biological conditions. Several biodegradable synthetic polymers, such as polycaprolactone (PCL), poly-L-lactic acid (PLA), and polybutylene terephthalate (PBT), among others, are frequently used to fabricate porous scaffold materials for tissue engineering applications [20-22]. The biodegradability of the scaffold materials can be tuned by using a suitable filler/additive in their matrices or blending with other polymers. Different metals and their oxides and carbon in various forms, such as graphene, carbon nanotubes (CNTs), fullerene, clay or modified clay, and zeolites, are intensively used to alter the properties of the pure polymers [23-26]. These nanomaterials have different kinds of morphology as well as orientation (1D, 2D, and 3D) that considerably influence the interactions between the polymer and nanomaterials, and consequently, cellular activities [27]. Although there are several reports available where scaffold materials have been utilized in the field of tissue engineering for medicine, surgery, and dental applications, their results exhibited that rapid regeneration of the damaged tissues, namely enamel, pulpodentin complex, periodontal apparatus, and teeth, occurred in the presence of the scaffold materials. It has been seen that the hard scaffolds are suitable for bone tissues, whereas soft and injectable scaffolds are more useful for pulpodentin and periodontal complexes. Stem cells in combination with scaffolds and signaling molecules, have been already developed for the regeneration of damaged dental tissues. However, several concerns, such as the safety and standardization of the techniques, still have to be resolved for clinical application in humans [28,29]. Herein, we have briefly described the major classes of the biodegradable polymer scaffolds and their effects on stem cell functions. We have also mentioned some common techniques of scaffold fabrication and their application. Moreover, we have endeavored to explain the effects of the different types of naturally derived ECM on immune responses. This review is focused on the different kinds of polymer scaffolds and their tissue engineering applications using stem cells.

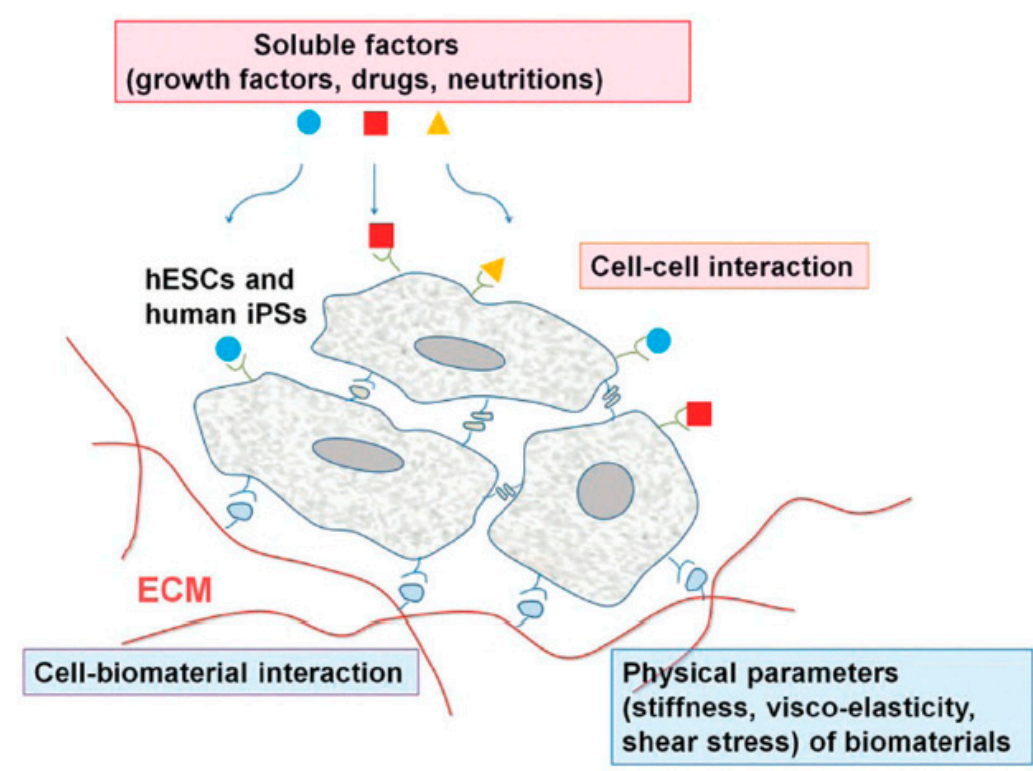

Figure 1. Schematic representation of the microenvironments and niches of stem cells and their regulation by the following factors: soluble factors, such as growth factors or cytokines, nutrients, and bioactive molecules; cell-cell interactions; and cell-biomaterial interactions. Physical properties of biomaterials also regulate the stem cell fate. Reproduced with permission from reference [5]; Copyright 2015, Royal Society of Chemistry. 


\section{Types of Polymer Scaffolds}

The scaffold materials are extensively used in tissue engineering fields due to their superior physiochemical properties. The physiochemical behaviors such as external geometry, surface properties, degradable nature, porosity and pore size, mechanical strength, biodegradability, and biocompatibility of the scaffolds play very important roles in cell adhesion and proliferation [30]. Figure 2 shows the flowchart for the generation of active tissues from biomaterials [31]. Here, we have described some common types of scaffolds and their advantages for tissue engineering.

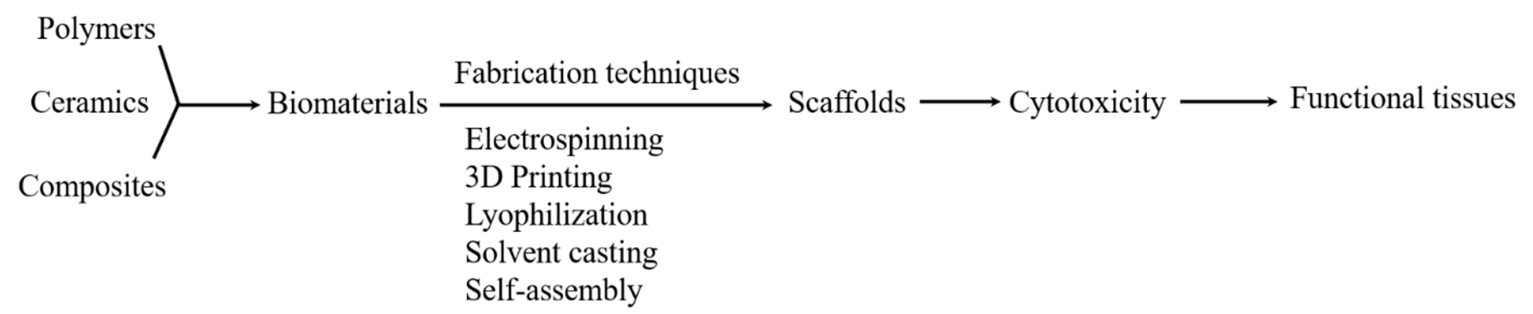

Figure 2. A flowchart for the generation of the functional tissues from biomaterials (from reference [31]).

\subsection{Three-Dimensional (3D) Polymer Scaffolds}

Three-dimensional (3D) printing techniques have received a great amount of attention in the field of tissue engineering owing to their ability to design and fabricate complex structures with high accuracy. In this process, the materials are deposited in a layer-by-layer fashion to form objects from 3D model data [32]. This is an attractive technique due to the high levels of build resolution, smooth surfaces, rapid building, good mechanical strength between the layers, and efficacy in printing clear objects, which are not achievable with the conventional 2D model [33]. It has been noted that the cell responses were different in the 3D microenvironments compared to those of 2D models [34]. The porous 3D scaffolds facilitate better cell-cell and cell-matrix interactions and lead to a significant enhancement of the cell densities compared to the 2D conditions [35]. Notably, better growth of blood vessels with increased nutrient, oxygen, and waste diffusion is possible in the 3D microenvironments [36-38]. Polylactic acid (PLA); polycarbonate (PC); acrylonitrile butadiene styrene; oligo-propylene fumarates; pluronic, alginate, gelatin, and hyaluronic acid; epoxy resins, etc. are frequently used in 3D-printing techniques for different applications [39-41]. The 3D-printed polymer materials can be used in the aerospace industry for the manufacturing of lightweight complex structures, the architectural industry for structural models, and also in artistic disciplines for artifact replication [42,43]. However, the weak mechanical strength of the 3D-printed polymer materials restricts it to use in load-bearing functional applications. The mechanical strength of printed materials can be improved by using a suitable filler in their matrix.

\subsection{Hydrogel Scaffolds}

Hydrogel scaffolds have acquired significant attention from researchers for their use as biomaterials for tissue engineering applications. The hydrogel can enable molecularly tuned biofunctions and adequate mechanical strength, as well as ECM-like conditions for better cellular activity. Hydrogel scaffold is the kind of structural support made by the bioactive compounds. Hydrogels are composed of the crosslinked networks of the polymer chains that are formed in the presence of water or a physiological medium [44]. This network structure gives the hydrogels a unique swelling potential and 3D skeleton. This network structure can be formed through the chemical interactions between the different functional groups present in the matrix or through physical interactions [45-47]. Depending on this structure, hydrogels may be chemically stable or unstable in nature, which influences the solubility of hydrogels in various solvents. The unstable gels are known as a reversible or physical gel and they are inhomogeneous in nature [48]. Different synthetic and natural polymers are often used for hydrogel synthesis. Hydrogels synthesized from the common synthetic and natural polymers are represented in 
Table 1 [49]. Naturally derived hydrogels have several advantages over synthetic polymer scaffolds in terms of their biocompatibility, cellular interactions, and degradation [49]. However, owing to their weak mechanical strength, hydrogel applications are restricted to limited fields. This drawback can be resolved for synthetic polymer-based hydrogels by controlling the structure or functional moieties of the polymer chains or by incorporating appropriate fillers/additives [15]. Biocompatible hydrogels are widely utilized in tissue engineering applications for wound healing, bone regeneration, drug transport, etc. [50]. Besides, hydrogels facilitate the development and differentiation of cells in newly developed tissues in the presence of growth factors [51]. Hydrogels also enable rapid nutrient exchange, cell migration, and angiogenesis [52]. 
Table 1. Some common synthetic and natural polymers used for hydrogel synthesis. Reproduced with permission from reference [49]; Copyright 2012, Elsevier.

\begin{tabular}{|c|c|c|c|c|c|c|}
\hline \multicolumn{4}{|c|}{ Natural Polymers and Their Derivatives ( \pm Crosslinkers) } & \multirow[b]{2}{*}{$\begin{array}{c}\text { Synthetic Polymers ( } \pm \text { Crosslinker) } \\
\text { Polyesters }\end{array}$} & \multirow[b]{2}{*}{$\begin{array}{c}\text { Other Polymers } \\
\text { PEG-bis-(PLA-acrylate), PEG } \pm \\
\text { cyclodextrin (CD), PEG-g- } \\
\text { poly(acrylamide(AAm)-co-Vamine), } \\
\text { poly(N- isopropylacrylamide-co- } \\
\text { acrylic acid) P(NIPAAm-co- AAc), } \\
\text { P(NIPAAm-co-ethyl methacrylate } \\
\text { (EMA), poly(vinyl acetate)- } \\
\text { poly(vinyl alcohol) (PVAc- PVA), } \\
\text { poly(N-vinyl pyrrolidone) (PNVP), } \\
\text { poly(methyl methacrylate-co- } \\
\text { hydroxyethyl methacrylate) } \\
\text { (PMMA-co-MEHA), } \\
\text { poly(acrylonitrile-co-allyl sulfonate), } \\
\text { poly(biscarboxy- } \\
\text { phenoxy-phosphazene), } \\
\text { poly(glucosylethylmethacrylate) } \\
\text { P(GEMA-sulfate) }\end{array}$} & \multirow[b]{2}{*}{ 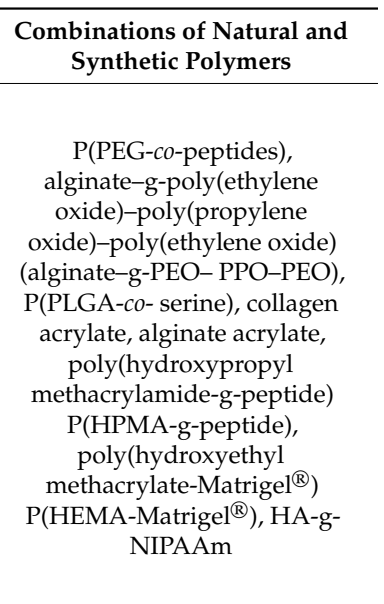 } \\
\hline $\begin{array}{l}\text { Anionic polymers: } \\
\text { Hyaluronic acid (HA), } \\
\text { alginic acid, pectin, } \\
\text { carrageenan, chondroitin } \\
\text { sulfate, dextran sulfate }\end{array}$ & $\begin{array}{c}\text { Cationic } \\
\text { polymers: } \\
\text { Chitosan, } \\
\text { polylysine }\end{array}$ & $\begin{array}{c}\text { Amphipathic } \\
\text { polymers: } \\
\text { Collagen (and } \\
\text { gelatin), } \\
\text { carboxymethyl chitin, } \\
\text { fibrin }\end{array}$ & $\begin{array}{l}\text { Neutral } \\
\text { polymers: } \\
\text { Dextran, } \\
\text { agarose, } \\
\text { pullulan }\end{array}$ & & & \\
\hline
\end{tabular}




\subsection{Fibrous and Porous Scaffolds}

Fibrous scaffolds are another important category of scaffolds and have gathered a lot of interest in tissue engineering applications for neural tissue engineering, bone, cartilage, skeletal muscle, and controlled delivery of small molecules such as drugs, DNA, and proteins [53]. The high aspect ratio of fibrous scaffolds with their intrinsic structure confers better cell adhesion, proliferation, migration, and differentiation $[54,55]$. Electrospinning, self-assembly, and phase separation techniques are used to fabricate the fibrous scaffolds. Among them, electrospinning is the most versatile technique used for the fabrication of nanofibers [56]. Various synthetic and natural polymers, such as PLA, polyurethane (PU), PCL, poly(lactic-co-glycolic acid) (PLGA), and collagen, among others [57-62], are commonly employed for nanofiber fabrication for different applications. The properties of fabricated nanofibers can be tuned by changing the functional groups of the pure polymer or blending with other materials. Fabrication of the small molecule-loaded nanofibers can be accomplished by direct mixing of the targeted molecules into the polymer solution [63]. Porous scaffolds, such as foam, with homogenous interconnected pore networks are also considered to be useful ECM platforms for biomedical applications [20]. The porous structure of the scaffold has an auxiliary advantage in cell adhesion and proliferation processes. This structure facilitates proper nutrient transport within the network structure and limits the cluster size to the pore size of the scaffolds. Moreover, the pore architectures can be optimized by exploiting a suitable solvent and phase separating conditions [64]. PLGA, PCL, poly(D,L-lactic acid) (PDLLA), and PBT are some of the synthetic polymers commonly applied for the fabrication of porous scaffolds $[21,22,65]$. Table 2 represents several common scaffold fabrication techniques and their applications in different fields. For naturally derived ECM, top-down as well as bottom-up approaches have been utilized, including ECM proteins and immunomodulatory domains, such as matrix metalloproteinase (MMP)-sensitive peptides, respectively.

Table 2. Common scaffold fabrication techniques and their applications.

\begin{tabular}{|c|c|c|c|}
\hline Method/Scaffold & Polymers Used & Applications & References \\
\hline \multicolumn{4}{|c|}{ For gel scaffold fabrication } \\
\hline Emulsification technique & $\begin{array}{l}\text { Collagen, gelatin, and hyaluronic acid } \\
\text { (HA) }\end{array}$ & Controlled drug delivery & {$[50,66,67]$} \\
\hline Micromolding process & $\begin{array}{l}\text { Poly(ethylene glycol) (PEG), HA, alginate, } \\
\text { poly(methyl methacrylate) (PMMA) }\end{array}$ & $\begin{array}{c}\text { Delivery of } \\
\text { small-molecule-like } \\
\text { drugs and insulin }\end{array}$ & [68-70] \\
\hline Microfluidics process & $\begin{array}{c}\text { Calcium alginate, PEG, silicon, } \\
\text { poly(dimethyl siloxane) (PDMS) }\end{array}$ & $\begin{array}{l}\text { Sensing, cell separation, } \\
\text { and controlled } \\
\text { microreactors }\end{array}$ & [71-73] \\
\hline $\begin{array}{l}\text { Photolithography } \\
\text { technique }\end{array}$ & $\begin{array}{c}\text { Chitosan, PMMA, PEG, } \\
\text { Poly(2-(trimethylamino)ethyl } \\
\text { methacrylate (PDMAEM) }\end{array}$ & $\begin{array}{l}\text { Cell-cell interactions, } \\
\text { biosensors, microdevices }\end{array}$ & [74-76] \\
\hline Injectable gel scaffold & $\begin{array}{c}\text { Copolymers of poly(lactic acid) (PLA), } \\
\text { poly(glycolic acid) (PGA), PEG, } \\
\text { poly(lactic-co-glycolic acid) (PLGA), } \\
\text { copolymers of poly(ethylene oxide) } \\
\text { (PEO), chitosan, collagen, and HA }\end{array}$ & $\begin{array}{c}\text { Cartilage and bone tissue } \\
\text { engineering, drug } \\
\text { delivery }\end{array}$ & [77-79] \\
\hline \multicolumn{4}{|c|}{ For porous scaffold fabrication } \\
\hline $\begin{array}{l}\text { Solvent casting/salt } \\
\text { leaching technique }\end{array}$ & $\begin{array}{l}\text { Collagen, PLGA, poly(L-lactic acid) } \\
\text { (PLLA) }\end{array}$ & $\begin{array}{l}\text { Cartilage and bone tissue } \\
\text { engineering, }\end{array}$ & [80-82] \\
\hline $\begin{array}{l}\text { Gas foaming/salt } \\
\text { leaching technique }\end{array}$ & $\begin{array}{l}\text { PLLA, PLGA, poly(D,L-lactic acid) } \\
\text { (PDLLA) }\end{array}$ & $\begin{array}{c}\text { Delivery of small } \\
\text { molecules such as drugs, } \\
\text { tissue engineering }\end{array}$ & [83-85] \\
\hline $\begin{array}{l}\text { Ice particle leaching } \\
\text { technique }\end{array}$ & PLLA and PLGA & Bone tissue engineering & [86-88] \\
\hline
\end{tabular}




\section{Impact of Scaffolds on Stem Cell Functions}

Scaffolds prepared from different techniques have different physiochemical properties, ranging from porous to fibrous, irregular to regular, and nanofibrous to microfibrous architectures, which have a great impact on stem cell functions, since the different structure, porosity, and surface roughness of each fabricated scaffold has a direct influence on cell growth and tissue regeneration. In this section, we have described the stem cell fate in the presence of different kinds of scaffolds by considering some common examples with good results. The surface topography from the micro- to nanoscale has a great influence on cell behavior, which can induce the direct osteogenesis of stem cells [89-91]. Kumar et al. fabricated PCL-based scaffolds with various structures, such as salt-leached scaffolds, gas-foamed scaffolds, gas-foamed phase-separated scaffolds, nanofiber scaffolds, and spin-coated films, and evaluated their topographical effects on stem cell fate. It was observed that only the nanofibrous scaffolds had the potential to drive human bone marrow stromal cells (hBMSCs) towards osteogenesis without any additional osteogenic supplements. Furthermore, the cell shape was also different on these scaffolds' surfaces. More elongated and highly branched cell morphologies were observed on nanofibrous surfaces in the absence of osteogenic supplements, whereas rounded and less branched morphologies appeared on the flat surface of the scaffolds in the absence of osteogenic supplements. This was due to the greater adhesion of hBMSCs to the nanofibrous surface that facilitates the osteogenesis and elongated, branched morphology. Figure 3 represents the cell morphologies cultured on different scaffold surfaces. These results indicate that cell behavior is highly influenced by the surface topography of the fabricated scaffolds and the scaffolds' potential can be altered by changing the scaffold structure [92].
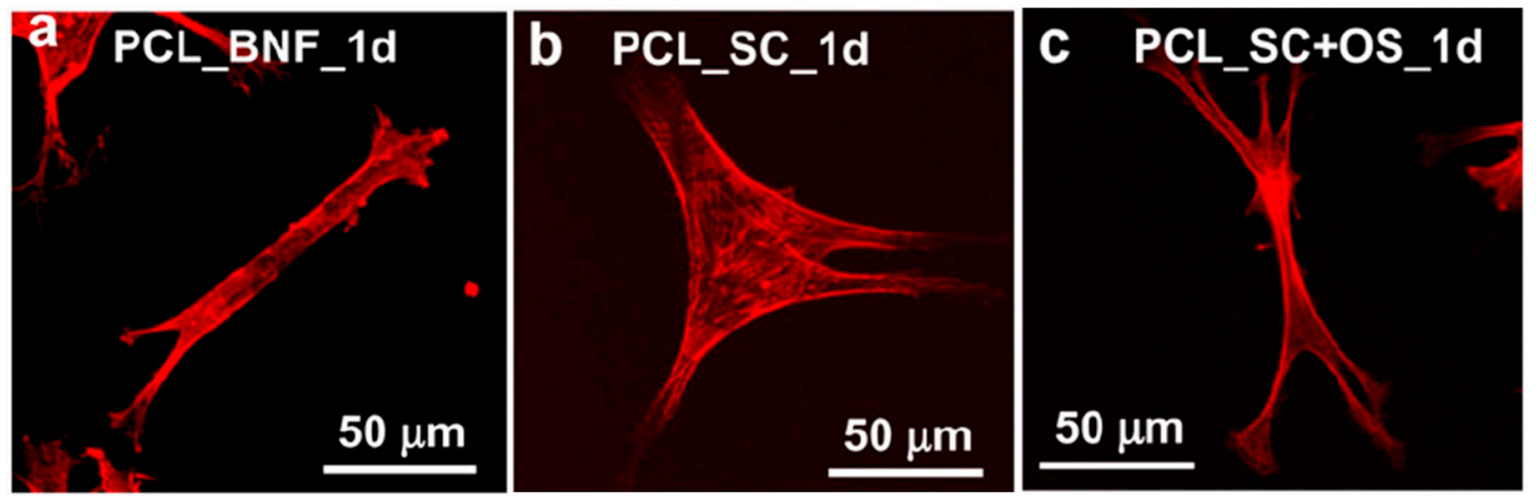

Figure 3. $(\mathbf{a}-\mathbf{c})$ Effect of different types of scaffolds on the morphology of human bone marrow stromal cells (hBMSC) $(400 \times$ ) after 1 day of culturing. (a) PCL_BNF: big nanofiber scaffolds $\sim 900 \mathrm{~nm}$ in diameter, (b) PCL_SC: thin film of PCL polymer produced through spin coating, and (c) PCL_SC+OS: thin film with osteogenic supplements, and 1_d: 1 day. Reproduced with permission from references [92]; Copyright 2011, Elsevier.

Altering the properties of the 3D scaffolds to improve tissue regeneration is a fundamental task for tissue engineering applications. It is well known that the fabrication of functionalized scaffold devices with biomolecules or with growth factors is expensive, and their life span is also limited [93]. Therefore, development of a stable, inexpensive scaffold device is an interesting goal for rapid tissue regeneration. It was noted that the open pore structure of freeform fabricated (FFF) scaffolds supported the rapid proliferation of hBMSCs, but limited osteogenic differentiation. However, electrospun nanofibers have the opposite effect. A combination of FFF and nanofiber scaffold properties will provide a suitable platform for the rapid proliferation as well as differentiation of stem cells. In another study, Kumar and coworkers fabricated FFF scaffolds of poly( $\varepsilon$-caprolactone) (PCL) polymer with roughened struts and evaluated their effects on stem cell proliferation and differentiation in a controlled fashion. They increased the surface roughness of developed FFF scaffolds through a solvent etching technique. It was interesting to note that the etched scaffolds appeared to induce 
the osteogenic differentiation of stem cells to a greater extent compared to the unetched scaffolds. Moreover, the proliferation potential was the same in both scaffolds. The cells were highly spread on the unetched scaffold's surface, while more rounded morphology was observed on the etched scaffold's surface. This indicates that stem cell fate is deeply affected by the roughness of the scaffolds [93]. Since it is well established that stem cells have the potential to differentiate into other types of cell, this potential can be utilized in the field of tissue engineering to solve the shortage of bone and cartilage tissues. Scaffolds play crucial roles in the adhesion, proliferation, and differentiation of stem cells. The chemical composition and physical structure are the important factors of the scaffolds, which suggest their range of applications. Various metals have excellent mechanical strength, which makes them suitable materials for tissue engineering. However, the lack of degradability under biological conditions restricts their wide applicability. Moreover, some ceramic materials such as calcium phosphate, hydroxyapatite, etc. possess superior differentiation potential, but due to poor mechanical strength, their applications are also limited. In contrast, the properties of polymers can be easily modified and they can be used for the fabrication of biomimetic scaffolds for tissue regeneration [94].

The most important challenge in the field of tissue engineering is the fabrication of scaffold devices that have adequate mechanical strength while helping to speed up the recovery of defective bone tissues. The effects of the highly porous 3D nanofibrous poly(L-lactic acid) (PLLA) scaffolds fabricated by a phase separation technique on hMSCs have been studied by Hu et al. Histological analysis and calcium content quantification results revealed that differentiation of hMSCs occurred on the nanofibrous scaffold surface. Detailed study indicated that nanofibrous scaffolds facilitated the development of both bone and cartilage tissues and had the potential for osteochondral construction [95]. It has been noted that the hard tissues such as bone and dentine have a rich source of collagen type I fibrous protein, which consists of $\sim 80-90 \%$ organic moieties and is frequently utilized as an ECM for these cells [96]. Pathogen transmission, immune response, and weak mechanical properties restrict its use as an ideal material for tissue engineering. These concerns can be resolved by using the synthetic polymer scaffolds which have suitable mechanical strength, flexible structures, and controlled degradation $[97,98]$. Dental pulp stem cells (DPSCs) have been considered a suitable cell source for dental tissue regeneration due to their ability to self-renew and excellent proliferation as well as differentiation potential $[99,100]$. A comparative study was done to evaluate the fate of DPSCs in the presence of nanofibrous (NF) and solid-walled (SW) poly(L-lactic acid) (PLLA) scaffolds. Notably, better cell adhesion, proliferation, and differentiation of DPSCs were reported on the NF scaffolds compared to those of the SW scaffolds. Significant enhancement in alkaline phosphatase (ALP) activity and odontogenic-related genes was observed in the presence of NF scaffolds compared to those of the SW scaffolds. Additionally, higher mineralization was reported in the NF scaffold condition. Furthermore, enhanced odontogenic differentiation and hard tissue formations were observed on the NF scaffolds compared to the SW scaffolds in nude mice after 8 weeks of transplantation [101]. This is attributed to the biomimetic porous structure of the scaffolds that provides the natural ECM microenvironment to the dentine tissue for proper cell attachment, proliferation, and tissue neogenesis [93]. Figure 4 represents the growth of DPSCs on NF and SW PLLA scaffolds at different time intervals. This result clearly indicates the presence of greater cell densities on NF scaffolds than SW scaffolds. NF scaffolds conferred better ECM conditions for cell attachment and differentiation compared to SW scaffolds [101]. 

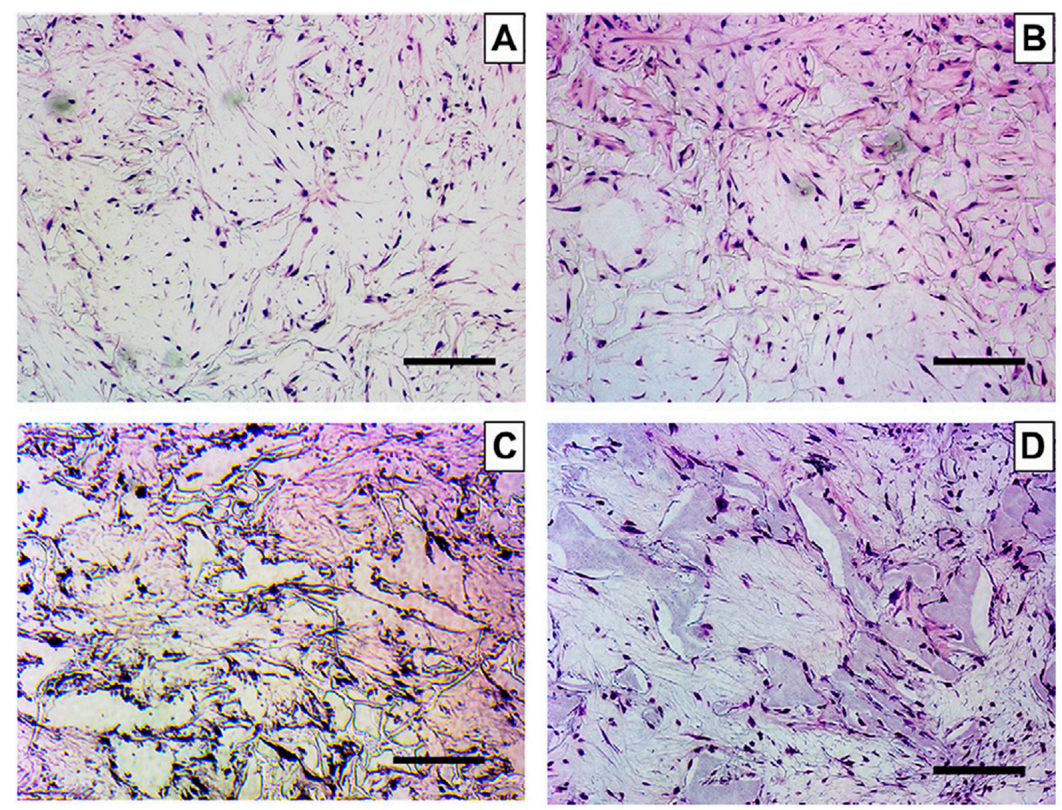

Figure 4. Hematoxylin and Eosin (H\&E) staining of human dental pulp stem cells (DPSCs) cultured on solid-walled (SW) and nanofibrous (NF) poly(L-lactic acid) (PLLA) scaffolds in odontogenic media: (A) on SW-PLLA scaffolds for 4 weeks; (B) on NF-PLLA scaffolds for 4 weeks; (C) on SW-PLLA scaffolds for 8 weeks; (D) on NF-PLLA scaffolds for 8 weeks. Scale bars represent $100 \mathrm{~mm}$. Reproduced with permission from reference [101]; Copyright 2011, Elsevier.

Chitosan, a natural biomaterial, is employed as an ECM platform for tissue engineering applications due to its superior physiochemical properties and excellent biocompatibility. It has been noted that induced chondrogenesis was observed in the presence of pure chitosan scaffolds. Ragetly et al. prepared type II collagen-coated chitosan fibrous scaffolds through a wet- spinning process and evaluated their effects on mesenchymal stem cells (MSCs) in terms of cell adhesion and chondrogenesis. The cell attachment is widely affected by the presence of type II collagen. Type I collagen has been more extensively applied for tissue engineering applications than type II collagen, so the utilization of type II collagen is more fascinating for the development of biomimetic scaffolds in the field of tissue engineering. An enhancement in cell adhesion as well as chondrogenesis was observed in the presence of the developed biomimetic scaffolds compared to the pure chitosan scaffolds. This improvement was due to the presence of type II collagen in biomimetic scaffolds, which facilitated the better cell attachment through interactions with different binding sites. Furthermore, an enhanced cell distribution was also observed in type II collagen- coated chitosan scaffolds. An improved amount and quality of the ECM was noted in type II collagen-coated scaffolds after 21 days of treatment compared to the pure chitosan scaffolds. This enhancement in ECM content is responsible for better cellular activity [102]. Biomaterial scaffolds play a critical role in the regulation of cell growth and differentiation through their mechanical support as well as geometry. Native ECM contains attractive materials for scaffold fabrication, such as alginate, collagen, etc., because of their specific cell proliferation and differentiation abilities [103-105]. Rowland and coworkers evaluated the effects of the different crosslinking agents on the chondrogenic differentiation of MSCs in the presence of cartilage-derived matrix (CDM) scaffolds. It was observed that the scaffolds developed from CDM conferred a chondroinductive microenvironment that facilitated cartilaginous matrix synthesis in the cells. However, the tendency of CDM to shrink in the cultured media restricts its potential broad application. The authors applied dehydrothermal (DHT) and ultraviolet light (UV) treatment and the chemical crosslinker carbodiimide (CAR) on the CDM scaffolds. It was interesting to note that the original shape of the CDM scaffolds was maintained despite these treatments. DHT and UV treatments facilitate cell attachment, while CAR treatment inhibits cell adhesion. Furthermore, the chondrogenic differentiation of MSCs is prominently 
affected by these treatments [106]. Cellular behavior is also affected by the surface properties such as the wettability, roughness, etc. of polymers, and this can be altered by changing the chemical components or by incorporating suitable fillers. Poly(caprolactone) (PCL) has gained a considerable amount of attention for use as a 3D-printed material for tissue engineering applications owing to its superior mechanical strength and biocompatibility [107,108]. Despite this promising potential, PCL is hydrophobic in nature, which may limit its range of applications. Rashad and coworkers fabricated PCL/cellulose nanofibril (CNF) 3D-printed scaffolds and evaluated the cellular responses using MSCs. The hydrophobic nature of the PCL polymer was tuned by incorporating the desired amount of multiscale hydrophilic and biocompatible CNF filler into the matrix. The significant enhancement in the hydrophilic properties of PCL scaffolds was observed in the presence of CNF. Live/dead staining and dehydrogenase release assay indicated that CNFs have no adverse effects on MSCs. An enhancement in cell viability, attachment, proliferation, and osteogenic differentiation of MSCs occurred in the presence of the PCL/CNF-based 3D-printed scaffolds compared to the pure PCL scaffolds. Furthermore, enhanced alkaline phosphatase (ALP) activity and collagen type I and mineral formations were observed in CNF-coated scaffolds. This enhancement was due to the wrapping of the hydrophilic CNFs by hydrophobic PCL layers, which provides a suitable platform for enhanced cellular activities. Figure 5 represents CNF-coated 3D scaffolds of PCL and their effects on MSC fate [109].

(i) $\mathrm{A}$

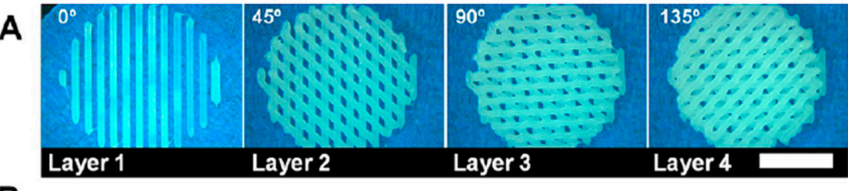

B

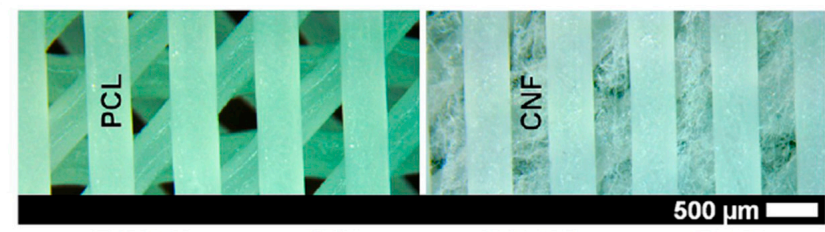

(ii)

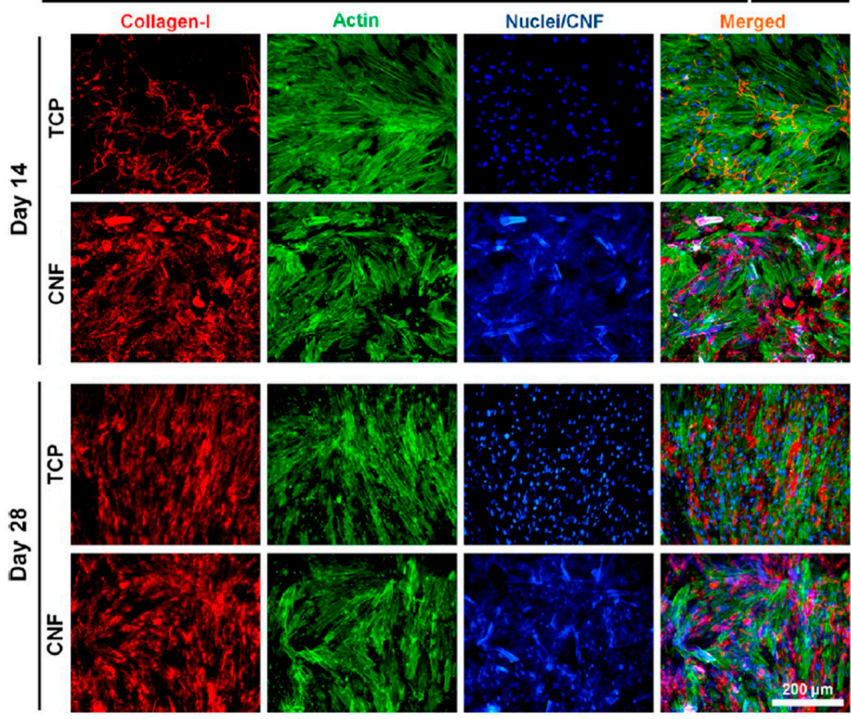

Figure 5. (i) Structural characterization of the 3D-printed PCL scaffolds. (A) Stereomicroscope images of the printed four layers with orientations of $0^{\circ}-45^{\circ}-90^{\circ}-135^{\circ}$ and strand spacing of $1 \mathrm{~mm}$ (scale bar: $5 \mathrm{~mm}$ ). (B) Stereomicroscope images of the 3D-printed PCL before and after coating with CNF, showing the cellulose fibers between the PCL strands. (ii) collagen type I production and actin cytoskeleton organization of cells after 14 and 21 days. Reproduced with permission from reference [109]; Copyright 2018, American Chemical Society. 
These results clearly indicate that the collagen type I production was higher in CNF-coated conditions than in the control. The proliferation and differentiation potential of hMSCs are highly governed by the material's nature, signaling patterns, and other external factors such as the magnetic and electric fields [110-113]. Hence, it is necessary to prepare the scaffolds with proper features that provide a better microenvironment for MSC growth. Jin et al. fabricated highly aligned nanofibers of poly(L-lactic acid) (PLLA) through an electrospinning technique, followed by surface polymerization with a conductive monomer of 3,4-ethoxylene dioxythiophene (EDOT), and evaluated their effects on MSCs under electric fields. Notably, better cell adhesion and proliferation were observed on the surface of fabricated nanofibers [114]. Impact of other scaffolds on stem cell functions is summarized in Table 3.

Table 3. Impact of other scaffolds materials on stem cell fate.

\begin{tabular}{|c|c|c|c|}
\hline Materials & Nature of Scaffold & $\begin{array}{c}\text { Impact on Different Stem } \\
\text { Cells }\end{array}$ & References \\
\hline $\begin{array}{l}\text { Calcium phosphate- chitosan } \\
\text { composite } \\
\text { Chitosan }\end{array}$ & $\begin{array}{l}\text { Injectable scaffolds } \\
\text { Fibrous scaffolds }\end{array}$ & $\begin{array}{c}\text { Cell proliferation and } \\
\text { osteogenic differentiation } \\
\text { Chondrogenesis }\end{array}$ & {$[115,116]$} \\
\hline $\begin{array}{c}\text { Poly(caprolactone) }(\mathrm{PCL}) \\
\text { Poly(L-lactic acid)-co- } \\
\text { poly(3-caprolactone)/ collagen } \\
\text { PCL/hydroxyapatite } \\
\text { PCL } \\
\text { PCL/polydopamine }\end{array}$ & $\begin{array}{l}\text { Freeform fabricated (FFF) } \\
\text { scaffolds } \\
\text { Nanofibrous scaffolds } \\
\text { Coiled scaffolds } \\
\text { Microfibrous scaffolds }\end{array}$ & $\begin{array}{c}\text { Cell proliferation and } \\
\text { differentiation } \\
\text { Hepatic trans-differentiation } \\
\text { Osteogenesis } \\
\text { Osteogenesis } \\
\text { Mild myofibroblastic } \\
\text { differentiation }\end{array}$ & {$[96,117-120]$} \\
\hline $\begin{array}{c}\text { Polyethylene oxide and poly(3- } \\
\text { hydroxybutyrate-co-3- } \\
\text { hydroxyvalerate) }\end{array}$ & Nanofibrous scaffolds & $\begin{array}{l}\text { Neuronal differentiation and } \\
\text { peripheral nerve regeneration }\end{array}$ & [121] \\
\hline $\begin{array}{c}\text { Cartilage-derived } \\
\text { Collagen/gold-coated collagen } \\
\text { Starch } \\
\text { Fibrin } \\
\text { Nanostructured } \\
\text { tendon-derived biomaterials }\end{array}$ & $\begin{array}{l}\text { Crosslinked scaffolds } \\
\text { Crosslinked scaffolds } \\
\text { Nanofibers } \\
\text { 3D scaffolds } \\
\text { Nanofibrous scaffolds }\end{array}$ & $\begin{array}{c}\text { Chondrogenesis } \\
\text { Chondrogenesis and } \\
\text { osteogenesis } \\
\text { Enhanced differentiation and } \\
\text { proliferation } \\
\text { Osteogenesis } \\
\text { Neuronal differentiation } \\
\text { Enhanced osteogenesis }\end{array}$ & [122-127] \\
\hline Poly(lactic acid)/silk fibroin & Nanofibrous scaffolds & Neuronal differentiation & [128] \\
\hline $\begin{array}{c}\text { Gelatin methacrylate } \\
\text { Gelatin } \\
\text { Hyaluronic acid (HA) } \\
\text { Poly(ethylene glycol) (PEG) }\end{array}$ & Hydrogels & $\begin{array}{l}\text { Neuronal differentiation } \\
\text { Enhanced osteogenesis } \\
\text { Cell differentiation }\end{array}$ & [129-132] \\
\hline $\begin{array}{l}\text { Graphene foam } \\
\text { Polyurethane foam }\end{array}$ & $3 \mathrm{D}$ porous structure & $\begin{array}{c}\text { Enhanced neuronal } \\
\text { differentiation } \\
\text { Promoted hepatogenesis }\end{array}$ & {$[133,134]$} \\
\hline $\begin{array}{l}\text { Conducting polymer } \\
\text { (CP)-based biomaterials }\end{array}$ & Thin film/nanofibers/scaffolds & Enhanced osteogenesis & [135-140] \\
\hline
\end{tabular}

It is well established that the scaffold materials closely resemble the native ECM and are frequently used in tissue engineering applications for replacing damaged or diseased tissues. Wang and coworkers developed the 3D-printed porous scaffolds from a poly(propylene fumarate) (PPF) resin and evaluated the cytotoxicity of the degraded scaffolds through (XTT assay). XTT (sodium 3'-[1-[(phenylamino)-carbonyl]-3, 4-tetrazolium]-bis (4-methoxy-6-nitro) benzene sulfonic acid hydrate is a tetrazolium salt, which form water-soluble formazan on bioreduction. Degradation is an important parameter of the polymer scaffolds, which indicates their durability. PPF has ester groups in its structure and can be hydrolyzed into fumaric acid and propylene glycol. It was seen that over a 224-day period, the 3D-printed polymer scaffolds were hydrolytically degraded and changes in their physical appearance, such as porosity and pore size, occurred. No significant decrease in fibroblast cell viability 
was observed in the presence of degraded scaffolds, indicating their biocompatibility. This result suggests that degradable, 3D-printed PPF scaffolds are an ideal material for tissue engineering, especially for bone tissues [141]. The effect of nanohydroxyapatite, antibiotic, and mucosal defensive agents on the mechanical and thermal properties of glass ionomer cement was evaluated by Chieruzzi et al. for clinical purposes. They noted the mechanical and thermal responses were deeply affected by the filler content [142]. Sometimes, inflammation has also been noted near the implantation site in the host [143]. Therefore, it is necessary to design materials that have the potential to regulate the host immune response directly [144]. Furthermore, many ECM has immunomodulatory domains that directly bind to the immune cells and regulate their functions [145]. An immunomodulatory response of naturally derived ECM materials is summarized in Table 4. A schematic representation of interactions between the ECM and immune cells is shown in Figure 6.

Table 4. Immunomodulatory impact of naturally derived ECM.

\begin{tabular}{ccc}
\hline Materials & Immunomodulatory Effect of the ECM & References \\
\hline $\begin{array}{c}\text { Collagen/chemically modified } \\
\text { collagen/denatured collagen (gelatin) }\end{array}$ & $\begin{array}{c}\text { Degranulation of peripheral basophils and } \\
\text { suppressed immune cell activity/lower } \\
\text { inflammatory response/anti-inflammatory } \\
\text { response }\end{array}$ & {$[146-149]$} \\
\hline Fibrin-based materials & Inflammatory anti-inflammatory effects & {$[150]$} \\
\hline Hyaluronic acid (HA) & $\begin{array}{c}\text { Dependent upon the molecular weight } \\
\text { (MW) of HA; high-MW HG was shown to } \\
\text { be inert or immunosuppressive, and } \\
\text { lower-MW HA provoked the inflammatory } \\
\text { response }\end{array}$ & {$[151-154]$} \\
\hline Decellularized matrices & Anti-inflammatory & {$[155-159]$} \\
\hline $\begin{array}{c}\text { Engineered ECM peptide-mimetic } \\
\text { materials }\end{array}$ & $\begin{array}{c}\text { Both anti-inflammatory and inflammatory } \\
\text { responses }\end{array}$ & {$[160-166]$} \\
\hline
\end{tabular}
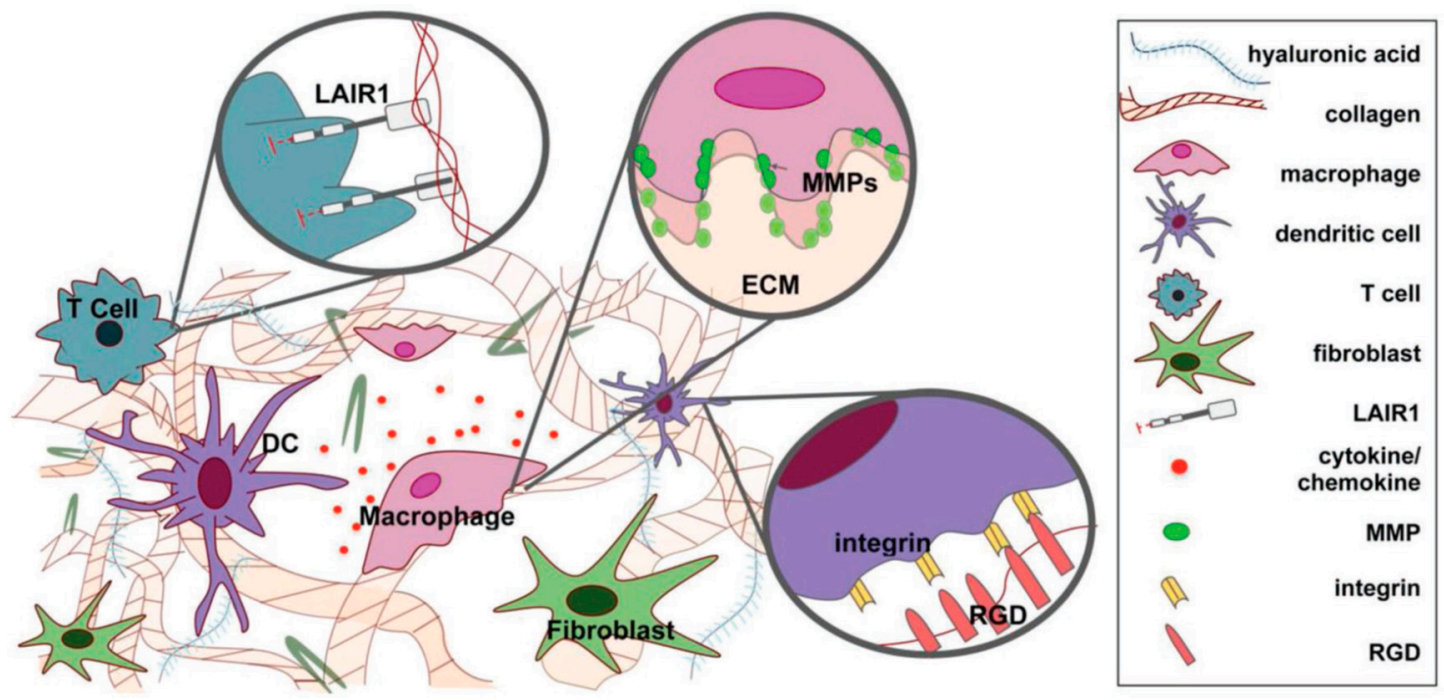

Figure 6. Schematic representation of ECM-immune cell interactions. Interactions include the LAIR1-collagen interaction that inhibits inflammatory signaling, matrix metalloproteinases (MMPs) that drive matrix degradation at cleavage motifs, and RGD (Arginylglycylaspartic acid) that facilitates cellular adhesion to ECM via integrin binding [150]; Copyright 2019, John Wiley and Sons. 


\section{Conclusions}

Several studies have been conducted to investigate the impact of scaffold materials on stem cell function. Synthetic as well as natural polymer scaffolds provide suitable microenvironments to the cells, enabling better attachment, proliferation, and differentiation. Modifications of natural or synthetic polymer scaffolds are required to meet the desired criteria of an ECM for enhanced cellular responses. Notably, better cell attachment, proliferation, and differentiation were observed on rough surfaces of scaffolds compared to smooth surfaces. In this review, we have described different kinds of scaffolds and their impact on stem cell activities. We hope that scaffold materials will become very practical and attractive tools for regenerative tissue engineering.

Author Contributions: This paper was written by D.K.P. and supported by K.-T.L.

Funding: This research was supported by Basic Science Research Program through the National Research Foundation of Korea (NRF) funded by the Ministry of Education (Nos. 2018R1A6A1A03025582 and 2018R1A6A1A0325582) and the National Research Foundation of Korea (NRF-2016R1D1A3B03932921).

Acknowledgments: The authors wish to thank all publishers for granting the copyright permissions.

Conflicts of Interest: The authors declare no conflict of interest.

\section{Abbreviations}

$\begin{array}{ll}\text { ECM } & \text { Extracellular matrix } \\ \text { hESCs } & \text { human embryonic stem cells } \\ \text { hiPSCs } & \text { human induced pluripotent stem cells } \\ \text { PCL } & \text { polycaprolactone } \\ \text { PLA } & \text { poly-L-lactic acid } \\ \text { PBT } & \text { polybutylene terephthalate } \\ \text { PU } & \text { polyurethane } \\ \text { MMP } & \text { matrix metalloproteinase }\end{array}$

\section{References}

1. Thomson, J.A.; Itskovitz-Eldor, J.; Shapiro, S.S.; Waknitz, M.A.; Swiergiel, J.J.; Marshall, V.S.; Jones, J.M. Embryonic stem cell lines derived from human blastocysts. Science 1998, 282, 1145-1147. [CrossRef] [PubMed]

2. Takahashi, K.; Tanabe, K.; Ohnuki, M.; Narita, M.; Ichisaka, T.; Tomoda, K.; Yamanaka, S. Induction of pluripotent stem cells from adult human fibroblasts by defined factors. Obstet. Gynecol. Surv. 2008, 63, 153. [CrossRef]

3. Yu, Y.; Gu, S.; Huang, H.; Wen, T. Combination of bFGF, heparin and laminin induce the generation of dopaminergic neurons from rat neural stem cells both in vitro and in vivo. J. Neurol. Sci. 2007, 255, 81-86. [CrossRef] [PubMed]

4. Higuchi, A.; Ling, Q.D.; Kumar, S.S.; Munusamy, M.A.; Alarfaj, A.A.; Chang, Y.; Kao, S.H.; Lin, K.C.; Wang, H.C.; Umezawa, A. Generation of pluripotent stem cells without the use of genetic material. Lab. Investig. 2014, 95, 26-42. [CrossRef] [PubMed]

5. Higuchi, A.; Ling, Q.D.; Kumar, S.S.; Chang, Y.; Alarfaj, A.A.; Munusamy, M.A.; Murugan, K.; Hsu, S.T.; Umezawa, A. Physical cues of cell culture materials lead the direction of differentiation lineages of pluripotent stem cells. J. Mater. Chem. B 2015, 3, 8032-8058. [CrossRef]

6. Higuchi, A.; Ling, Q.D.; Hsu, S.T.; Umezawa, A. Biomimetic cell culture proteins as extracellular matrices for stem cell differentiation. Chem. Rev. 2012, 112, 4507-4540. [CrossRef] [PubMed]

7. Kim, B.S.; Park, I.K.; Hoshiba, T.; Jiang, H.L.; Choi, Y.J.; Akaike, T.; Cho, C.S. Design of artificial extracellular matrices for tissue engineering. Prog. Polym. Sci. 2011, 36, 238-268. [CrossRef]

8. Li, X.; Katsanevakis, E.; Liu, X.; Zhang, N.; Wen, X. Engineering neural stem cell fates with hydrogel design for central nervous system regeneration. Prog. Polym. Sci. 2012, 37, 1105-1129. [CrossRef]

9. Kundu, B.; Kundu, S. Osteogenesis of human stem cells in silk biomaterial for regenerative therapy. Prog. Polym. Sci. 2010, 35, 1116-1127. [CrossRef] 
10. Aizawa, Y.; Owen, S.C.; Shoichet, M.S. Polymers used to influence cell fate in 3D geometry: New trends. Prog. Polym. Sci. 2012, 37, 645-658. [CrossRef]

11. Rodda, A.E.; Meagher, L.; Nisbet, D.R.; Forsythe, J.S. Specific control of cell-material interactions: Targeting cell receptors using ligand-functionalized polymer substrates. Prog. Polym. Sci. 2014, 39, 1312-1347. [CrossRef]

12. Place, E.S.; Evans, N.D.; Stevens, M.M. Complexity in biomaterials for tissue engineering. Nat. Mater. 2009, 8, 457-470. [CrossRef] [PubMed]

13. Cheng, J.Q.; Ma, H.W.; Xie, X.; Lu, Y.; Zhang, Y.B.; Dong, S.X.; Wang, T.Z.; Liu, Y.M.; Ling, W.H.; Hao, Y.T. Sero-epidemiological investigation on Hepatitis B among permanent residents in Shenzhen area. Zhonghua Liu Xing Bing Xue Za Zhi 2013, 34, 1179-1182. [PubMed]

14. Yin, Y.; Huang, P.; Han, Z.; Wei, G.; Zhou, C.; Wen, J.; Su, B.; Wang, X.; Wang, Y. Collagen nanofibers facilitated presynaptic maturation in differentiated neurons from spinal-cord-derived neural stem cells through MAPK/ERK1/2-Synapsin I signaling pathway. Biomacromolecules 2014, 15, 2449-2460. [CrossRef] [PubMed]

15. Dhandayuthapani, B.; Yoshida, Y.; Maekawa, T.; Kumar, D.S. Polymeric scaffolds in tissue engineering application: A review. Int. J. Polym. Sci. 2011, 2011, 1-19. [CrossRef]

16. Singh, A.; Elisseeff, J. Biomaterials for stem cell differentiation. J. Mater. Chem. 2010, 20, 8832. [CrossRef]

17. Ramakrishna, S.; Mayer, J.; Wintermantel, E.; Leong, K.W. Biomedical applications of polymer-composite materials: A review. Compos. Sci. Technol. 2001, 61, 1189-1224. [CrossRef]

18. Yannas, I.V. Suppression of in vivo degradability and of immunogenicity of collagen by reaction with glycosaminoglycans. Polym. Prepr. 1975, 16, 209-214.

19. Gunatillake, P.; Adhikari, R. Biodegradable synthetic polymers for tissue engineering. Eur. Cells Mater. 2003, 5, 1-16. [CrossRef]

20. Zhang, R.; Ma, P.X. Porous poly(L-lactic acid)/apatite composites created by biomimetic process. J. Biomed. Mater. Res. 1999, 45, 285-293. [CrossRef]

21. Hou, Q.; Grijpma, D.W.; Feijen, J. Porous polymeric structures for tissue engineering prepared by a coagulation, compression moulding and salt leaching technique. Biomaterials 2003, 24, 1937-1947. [CrossRef]

22. Hou, Q.; Grijpma, D.W.; Feijen, J. Preparation of porous poly( $\varepsilon$-caprolactone) structures. Macromol. Rapid Commun. 2002, 23, 247-252. [CrossRef]

23. Wang, X.; Hu, Y.; Song, L.; Yang, H.; Xing, W.; Lu, H. In situ polymerization of graphene nanosheets and polyurethane with enhanced mechanical and thermal properties. J. Mater. Chem. 2011, 21, 4222-4227. [CrossRef]

24. Li, F.; Qi, L.; Yang, J.; Xu, M.; Luo, X.; Ma, D. Polyurethane/conducting carbon black composites: Structure, electric conductivity, strain recovery behavior, and their relationships. J. Appl. Polym. Sci. 2000, 75, 68-77. [CrossRef]

25. Lee, H.T.; Lin, L.H. Waterborne polyurethane/clay nanocomposites: Novel effect of the clay and its interlayer ions on the morphology and physical and electrical properties. Macromolecules 2006, 39, 6133-6134. [CrossRef]

26. Wang, Q.; O'Hare, D. Recent advances in the synthesis and application of layered doublehydroxide (LDH) nanosheets. Chem. Rev. 2012, 112, 4124-4155. [CrossRef] [PubMed]

27. Patel, D.K.; Biswas, A.; Maiti, P. Nanoparticle-induced phenomena in polyurethanes. In Advances in Polyurethane Biomaterials; Woodhead Publishing: Sawston, UK, 2016. [CrossRef]

28. Chieruzzi, M.; Pagano, S.; Moretti, S.; Pinna, R.; Milia, E.; Torre, L.; Eramo, S. Nanomaterials for tissue engineering in dentistry. Nanomaterials 2016, 6, 134. [CrossRef]

29. O'Brien, F. Biomaterials and scaffolds for tissue engineering. Mater. Today 2011, 14, 88-95. [CrossRef]

30. Boyan, B.D.; Hummert, T.W.; Dean, D.D.; Schwartz, Z. Role of material surfaces in regulating bone and cartilage cell response. Biomaterials 1996, 17, 137-146. [CrossRef]

31. Jammalamadaka, U.; Tappa, K. Recent advances in biomaterials for 3D printing and tissue engineering. J. Funct. Biomater. 2018, 9, 22. [CrossRef]

32. Standard, A. F2792 Standard Terminology for Additive Manufacturing Technologies; ASTM International: West Conshohocken, PA, USA, 2012.

33. Stansbury, J.; Idacavage, M. 3D printing with polymers: Challenges among expanding options and opportunities. Dent. Mater. 2016, 32, 54-64. [CrossRef] [PubMed] 
34. Shachar, M.; Cohen, S. Cardiac tissue engineering, ex-vivo: Design principles in biomaterials and bioreactors. Heart Fail. Rev. 2003, 8, 271-276. [CrossRef] [PubMed]

35. Billiet, T.; Vandenhaute, M.; Schelfhout, J.; Van Vlierberghe, S.; Dubruel, P. A review of trends and limitations in hydrogel-rapid prototyping for tissue engineering. Biomaterials 2012, 33, 6020-6041. [CrossRef] [PubMed]

36. Malda, J.; Woodfield, T.B.; Van Der Vloodt, F.; Kooy, F.K.; Martens, D.E.; Tramper, J.; van Blitterswijk, C.A.; Riesle, J. The effect of PEGT/PBT scaffold architecture on oxygen gradients in tissue engineered cartilaginous constructs. Biomaterials 2004, 25, 5773-5780. [CrossRef] [PubMed]

37. Billiet, T.; Gevaert, E.; De Schryver, T.; Cornelissen, M.; Dubruel, P. The 3D printing of gelatin methacrylamide cell-laden tissue-engineered constructs with high cell viability. Biomaterials 2014, 35, 49-62. [CrossRef] [PubMed]

38. Miller, J.S.; Stevens, K.R.; Yang, M.T.; Baker, B.M.; Nguyen, D.H.T.; Cohen, D.M.; Toro, E.; Chen, A.A.; Galie, P.A.; Yu, X.; et al. Rapid casting of patterned vascular networks for perfusable engineered three dimensional tissues. Nat. Mater. 2012, 11, 768-774. [CrossRef] [PubMed]

39. Song, S.J.; Choi, J.; Park, Y.D.; Hong, S.; Lee, J.J.; Ahn, C.B.; Choi, H.; Sun, K. Sodium alginate hydrogel-based bioprinting using a novel multinozzle bioprinting system. Artif. Org. 2011, 35, 1132-1136. [CrossRef] [PubMed]

40. Highley, C.B.; Rodell, C.B.; Burdick, J.A. Burdick, Direct 3D printing of shear-thinning hydrogels into self-healing hydrogels. Adv. Mater. 2015, 27, 5075-5079. [CrossRef] [PubMed]

41. Wang, X.; Jiang, M.; Zhou, Z.; Gou, J.; Hui, D. 3D printing of polymer matrix composites: A review and prospective. Compos. Part. B 2017, 110, 442-458. [CrossRef]

42. Kroll, E.; Artzi, D. Enhancing aerospace engineering students learning with 3D printing wind-tunnel models. Rapid Prototyp. J. 2011, 17, 393-402. [CrossRef]

43. Wong, K.V.; Hernandez, A. A review of additive manufacturing. ISRN Mech. Eng. 2012, 2012, 208760-208770. [CrossRef]

44. Klouda, L.; Mikos, A. Thermoresponsive hydrogels in biomedical applications. Eur. J. Pharm. Biopharm. 2008, 68, 34-45. [CrossRef] [PubMed]

45. Peppas, N.A.; Mikos, A.G. Preparation methods and structure of hydrogels. In Hydrogels in Medicine and Pharmacy; Peppas, N.A., Ed.; CRC Press: Boca Raton, FL, USA, 1986; Volume 1, pp. 1-25.

46. Peppas, N.A. Hydrogels in Biomaterials Science, an Introduction to Materials in Medicine; Academic Press: San Diego, CA, USA, 1996; pp. 60-64.

47. Hoffman, A. Hydrogels for biomedical applications. Adv. Drug Deliv. Rev. 2002, 54, 3-12. [CrossRef]

48. Campoccia, D.; Doherty, P.; Radice, M.; Brun, P.; Abatangelo, G.; Williams, D.F. Semisynthetic resorbable materials from hyaluronan esterification. Biomaterials 1998, 19, 2101-2127. [CrossRef]

49. Hoffman, A. Hydrogels for biomedical applications*. Adv. Drug Deliv. Rev. 2012, 64, 18-23. [CrossRef]

50. Peppas, N.A.; Khare, A.R. Preparation, structure and diffusional behavior of hydrogels in controlled release. Adv. Drug Deliv. Rev. 1993, 11, 1-35. [CrossRef]

51. Tabata, Y. Tissue regeneration based on growth factor release. Tissue Eng. 2003, 9, 5-15. [CrossRef]

52. Bryant, S.J.; Anseth, K.S. The effects of scaffold thickness on tissue engineered cartilage in photo cross-linked poly(ethylene oxide) hydrogels. Biomaterials 2001, 22, 619-626. [CrossRef]

53. Vasita, R.; Katti, D.S. Nanofibers and their applications in tissue engineering. Int. J. Nanomed. 2006, 1, 15-30. [CrossRef]

54. Bhattarai, S.R.; Bhattarai, N.; Yi, H.K.; Hwang, P.H.; Cha, D.I.; Kim, H.Y. Novel biodegradable electrospun membrane: Scaffold for tissue engineering. Biomaterials 2004, 25, 2595-2602. [CrossRef]

55. Ma, Z.; Kotaki, M.; Inai, R.; Ramakrishna, S. Potential of nanofiber matrix as tissue-engineering scaffolds. Tissue Eng. 2005, 11, 101-109. [CrossRef] [PubMed]

56. Berndt, P.; Fields, G.B.; Tirrell, M. Synthetic lipidation of peptides and amino acids: Monolayer structure and properties. J. Am. Chem. Soc. 1995, 117, 9515-9522. [CrossRef]

57. Yang, F.; Murugan, R.; Wang, S.; Ramakrishna, S. Electrospinning of nano/micro scale poly(L-lactic acid) aligned fibers and their potential in neural tissue engineering. Biomaterials 2005, 26, 2603-2610. [CrossRef] [PubMed]

58. Riboldi, S.A.; Sampaolesi, M.; Neuenschwander, P.; Cossu, G.; Mantero, S. Electrospun degradable polyesterurethane membranes: Potential scaffolds for skeletal muscle tissue engineering. Biomaterials 2005, 26, 4606-4615. [CrossRef] [PubMed] 
59. Li, W.J.; Danielson, K.G.; Alexander, P.G.; Tuan, R.S. Biological response of chondrocytes cultured in three-dimensional nanofibrous poly( $\varepsilon$-caprolactone) scaffolds. J. Biomed. Mater. Res. A 2003, 67, 1105-1114. [CrossRef] [PubMed]

60. Uematsu, K.; Hattori, K.; Ishimoto, Y.; Yamauchi, J.; Habata, T.; Takakura, Y.; Ohgushi, H.; Fukuchi, T.; Sato, M. Cartilage regeneration using mesenchymal stem cells and a three-dimensional poly-lactic-glycolic acid (PLGA) scaffold. Biomaterials 2005, 26, 4273-4279. [CrossRef] [PubMed]

61. Matthews, J.A.; Wnek, G.E.; Simpson, D.G.; Bowlin, G.L. Electrospinning of collagen nanofibers. Biomacromolecules 2002, 3, 232-238. [CrossRef] [PubMed]

62. Zhang, Y.; Ouyang, H.; Lim, C.T.; Ramakrishna, S.; Huang, Z.M. Electrospinning of gelatin fibers and gelatin/PCL composite fibrous scaffolds. J. Biomed. Mater. Res. B 2005, 72, 156-165. [CrossRef] [PubMed]

63. Verreck, G.; Chun, I.; Rosenblatt, J.; Peeters, J.; Van Dijck, A.; Mensch, J.; Noppe, M.; Brewster, M.E. Incorporation of drugs in an amorphous state into electrospun nanofibers composed of a water-insoluble, nonbiodegradable polymer. J. Control. Release 2003, 92, 349-360. [CrossRef]

64. Ma, P.X.; Zhang, R. Microtubular architecture of biodegradable polymer scaffolds. J. Biomed. Mater. Res. 2001, 56, 469-477. [CrossRef]

65. Wei, G.; Ma, P.X. Structure and properties of nanohydroxyapatite/polymer composite scaffolds for bone tissue engineering. Biomaterials 2004, 25, 4749-4757. [CrossRef] [PubMed]

66. Alexakis, T.; Boadi, D.K.; Quong, D.; Groboillot, A.; O'neill, I.; Poncelet, D.; Neufeld, R.J. Microencapsulation of DNA within alginate microspheres and crosslinked chitosan membranes for in vivo application. Appl. Biochem. Biotechnol. 1995, 50, 93-106. [CrossRef] [PubMed]

67. Reis, C.P.; Ribeiro, A.J.; Neufeld, R.J.; Veiga, F. Alginate microparticles as novel carrier for oral insulin delivery. Biotechnol. Bioeng. 2007, 96, 977-989. [CrossRef] [PubMed]

68. Yeh, J.; Ling, Y.; Karp, J.M.; Gantz, J.; Chandawarkar, A.; Eng, G.; Blumling, J., III; Langer, R.; Khademhosseini, A. Micro molding of shape controlled, harvestable cell-laden hydrogels. Biomaterials 2006, 27, 5391-5398. [CrossRef] [PubMed]

69. Fukuda, J.; Khademhosseini, A.; Yeo, Y.; Yang, X.; Yeh, J.; Eng, G.; Blumling, J.; Wang, C.F.; Kohane, D.S.; Langer, R. Micro molding of photo cross linkable chitosan hydrogel for spheroid microarray and co-cultures. Biomaterials 2006, 27, 5259-5267. [CrossRef] [PubMed]

70. Khademhosseini, A.; Eng, G.; Yeh, J.; Fukuda, J.; Blumling, J., III; Langer, R.; Burdick, J.A. Micro molding of photo crosslinkable hyaluronic acid for cell encapsulation and entrapment. J. Biomed. Mater. Res. A 2006, 79, 522-532. [CrossRef]

71. Nisisako, T.; Torii, T.; Higuchi, T. Droplet formation in a microchannel network. Lab. Chip Miniat. Chem. Biol. 2002, 2, 24-26. [CrossRef] [PubMed]

72. Burdick, J.A.; Khademhosseini, A.; Langer, R. Fabrication of gradient hydrogels using a microfluidics/photo polymerization process. Langmuir 2004, 20, 5153-5156. [CrossRef]

73. Xu, S.; Nie, Z.; Seo, M.; Lewis, P.; Kumacheva, E.; Stone, H.A.; Garstecki, P.; Weibel, D.B.; Gitlin, I.; Whitesides, G.M. Generation of monodisperse particles by using microfluidics: Control over size, shape, and composition. Angew. Chem. Int. Ed. 2005, 44, 724-728. [CrossRef]

74. Beebe, D.J.; Moore, J.S.; Bauer, J.M.; Yu, Q.; Liu, R.H.; Devadoss, C.; Jo, B.H. Functional hydrogel structures for autonomous flow control inside microfluidic channels. Nature 2000, 404, 588-590. [CrossRef]

75. Liu, V.A.; Bhatia, S.N. Three-dimensional photo-patterning of hydrogels containing living cells. Biomed. Microdevice 2002, 4, 257-266. [CrossRef]

76. Dendukuri, D.; Pregibon, D.C.; Collins, J.; Hatton, T.A.; Doyle, P.S. Continuous-flow lithography for high-throughput microparticle synthesis. Nat. Mater. 2006, 5, 365-369. [CrossRef] [PubMed]

77. Jeong, B.; Bae, Y.H.; Kim, S.W. Thermoreversible gelation of PEG-PLGA-PEG triblock copolymer aqueous solutions. Macromolecules 1999, 32, 7064-7069. [CrossRef]

78. Ibusuki, S.; Fujii, Y.; Iwamoto, Y.; Matsuda, T. Tissue engineered cartilage using an injectable and in situ gelable thermoresponsive gelatin: Fabrication and in vitro performance. Tissue Eng. 2003, 9, 371-384. [CrossRef] [PubMed]

79. Seong, J.Y.; Jun, Y.J.; Jeong, B.; Sohn, Y.S. New thermogelling poly(organophosphazenes) with methoxypoly(ethylene glycol) and oligopeptide as side groups. Polymer 2005, 46, 5075-5081. [CrossRef]

80. Mikos, A.G.; Sarakinos, G.; Leite, S.M.; Vacant, J.P.; Langer, R. Laminated three-dimensional biodegradable foams for use in tissue engineering. Biomaterials 1993, 14, 323-330. [CrossRef] 
81. Mikos, A.G.; Thorsen, A.J.; Czerwonka, L.A.; Bao, Y.; Langer, R.; Winslow, D.N.; Vacanti, J.P. Preparation and characterization of poly(L-lactic acid) foams. Polymer 1994, 35, 1068-1077. [CrossRef]

82. Ochi, K.; Chen, G.; Ushida, T.; Gojo, S.; Segawa, K.; Tai, H.; Ueno, K.; Ohkawa, H.; Mori, T.; Yamaguchi, A.; et al. Use of isolated mature osteoblasts in abundance acts as desired-shaped bone regeneration in combination with amodified poly-DL-lacticco-glycolic acid (PLGA)-collagen sponge. J. Cell. Physiol. 2003, 194, 45-53. [CrossRef]

83. Mooney, D.J.; Baldwin, D.F.; Suh, N.P.; Vacanti, J.P.; Langer, R. Novel approach to fabricate porous sponges of poly(D,L-lactic-co-glycolic acid) without the use of organic solvents. Biomaterials 1996, 17, 1417-1422. [CrossRef]

84. Yoon, J.J.; Park, T.G. Degradation behaviors of biodegradable macroporous scaffolds prepared by gas foaming of effervescent salts. J. Biomed. Mater. Res. 2001, 55, 401-408. [CrossRef]

85. Murphy, W.L.; Dennis, R.G.; Kileny, J.L.; Mooney, D.J. Salt fusion: An approach to improve pore interconnectivity within tissue engineering scaffolds. Tissue Eng. 2002, 8, 43-52. [CrossRef] [PubMed]

86. Holy, C.E.; Shoichet, M.S.; Davies, J.E. Engineering three-dimensional bone tissue in vitro using biodegradable scaffolds: Investigating initial cell-seeding density and culture period. J. Biomed. Mater. Res. 2000, 51, 376-382. [CrossRef]

87. Karp, J.M.; Shoichet, M.S.; Davies, J.E. Bone formation on two-dimensional poly(DL-lactide-co-glycolide) (PLGA) films and three-dimensional PLGA tissue engineering scaffolds in vitro. J. Biomed. Mater. Res. A 2003, 64, 388-396. [CrossRef] [PubMed]

88. Kang, H.G.; Kim, S.Y.; Lee, Y.M. Novel porous gelatin scaffolds by overrun/particle leaching process for tissue engineering applications. J. Biomed. Mater. Res. B 2006, 79, 388-397. [CrossRef] [PubMed]

89. Dalby, M.J.; Riehle, M.O.; Johnstone, H.J.H.; Affrossman, S.; Curtis, A.S.G. Polymer-demixed nanotopography: Control of fibroblast spreading and proliferation. Tissue Eng. 2002, 8, 1099-1108. [CrossRef] [PubMed]

90. Thapa, A.; Miller, D.C.; Webster, T.J.; Haberstroh, K.M. Nano-structured polymers enhance bladder smooth muscle cell function. Biomaterials 2003, 24, 2915-2926. [CrossRef]

91. Lovmand, J.; Justesen, J.; Foss, M.; Lauridsen, R.H.; Lovmand, M.; Modin, C.; Besenbacher, F.; Pedersen, F.S.; Duch, M. The use of combinatorial topographical libraries for the screening of enhanced osteogenic expression and mineralization. Biomaterials 2009, 30, 2015-2022. [CrossRef]

92. Kumar, G.; Tison, C.K.; Chatterjee, K.; Pine, P.S.; McDaniel, J.H.; Salit, M.L.; Young, M.F.; Simon, C.G., Jr. The determination of stem cell fate by 3D scaffold structures through the control of cell shape. Biomaterials 2011, 32, 9188-9196. [CrossRef]

93. Kumar, G.; Waters, M.S.; Farooque, T.M.; Young, M.F.; Simon, C.G., Jr. Freeform fabricated scaffolds with roughened struts that enhance both stem cell proliferation and differentiation by controlling cell shape. Biomaterials 2012, 33, 4022-4030. [CrossRef]

94. Ma, P. Biomimetic materials for tissue engineering. Adv. Drug Deliv. Rev. 2008, 60, 184-198. [CrossRef]

95. Hu, J.; Feng, K.; Liu, X.; Ma, P.X. Chondrogenic and osteogenic differentiations of human bone marrow-derived mesenchymal stem cells on a nanofibrous scaffold with designed pore network. Biomaterials 2009, 30, 5061-5067. [CrossRef] [PubMed]

96. Wiesmann, H.P.; Meyer, U.; Plate, U.; Hohling, H.J. Aspects of collagen mineralization in hard tissue formation. Int. Rev. Cytol. 2005, 242, 121-156. [PubMed]

97. Duailibi, M.T.; Duailibi, S.E.; Young, C.S.; Bartlett, J.D.; Vacanti, J.P.; Yelick, P.C. Bioengineered teeth from cultured rat tooth bud cells. J. Dent. Res. 2004, 83, 523-528. [CrossRef] [PubMed]

98. Young, C.S.; Abukawa, H.; Asrican, R.; Ravens, M.; Troulis, M.J.; Kaban, L.B.; Vacanti, J.P.; Yelick, P.C. Tissue-engineered hybrid tooth and bone. Tissue Eng. 2005, 11, 1599-1610. [CrossRef] [PubMed]

99. Gronthos, S.; Mankani, M.; Brahim, J.; Robey, P.G.; Shi, S. Postnatal human dental pulp stem cells (DPSCs) in vitro and in vivo. Proc. Natl. Acad. Sci. USA 2000, 97, 13625-13630. [CrossRef] [PubMed]

100. Gronthos, S.; Brahim, J.; Li, W.; Fisher, L.W.; Cherman, N.; Boyde, A.; DenBesten, P.; Robey, P.G.; Shi, S. Stem cell properties of human dental pulp stem cells. J. Dent. Res. 2002, 81, 531-535. [CrossRef] [PubMed]

101. Wang, J.; Ma, H.; Jin, X.; Hu, J.; Liu, X.; Ni, L.; Ma, P.X. The effect of scaffold architecture on odontogenic differentiation of human dental pulp stem cells. Biomaterials 2011, 32, 7822-7830. [CrossRef]

102. Ragetly, G.; Griffon, D.J.; Chung, Y.S. The effect of type II collagen coating of chitosan fibrous scaffolds on mesenchymal stem cell adhesion and chondrogenesis. Acta Biomater. 2010, 6, 3988-3997. [CrossRef]

103. Badylak, S. The extracellular matrix as a biologic scaffold material. Biomaterials 2007, 28, 3587-3593. [CrossRef] 
104. Reilly, G.; Engler, A. Intrinsic extracellular matrix properties regulate stem cell differentiation. J. Biomech. 2010, 43, 55-62. [CrossRef]

105. Cornwell, K.G.; Landsman, A.; James, K.S. Extracellular matrix biomaterials for soft tissue repair. Clin. Podiatr. Med. Surg. 2009, 26, 507-523. [CrossRef] [PubMed]

106. Rowland, C.R.; Lennon, D.P.; Caplan, A.I.; Guilak, F. The effects of crosslinking of scaffolds engineered from cartilage ECM on the chondrogenic differentiation of MSCs. Biomaterials 2013, 34, 5802-5812. [CrossRef] [PubMed]

107. Woodruff, M.; Hutmacher, D. The return of a forgotten polymer-Polycaprolactone in the 21st century. Prog. Polym. Sci. 2010, 35, 1217-1256. [CrossRef]

108. Olubamiji, A.D.; Izadifar, Z.; Si, J.L.; Cooper, D.M.; Eames, B.F.; Chen, D.X. Modulating mechanical behavior of 3D-printed cartilage-mimetic PCL scaffolds: Influence of molecular weight and pore geometry. Biofabrication 2016, 8, 025020. [CrossRef] [PubMed]

109. Rashad, A.; Mohamed-Ahmed, S.; Ojansivu, M.; Berstad, K.; Yassin, M.A.; Kivijärvi, T.; Heggset, E.B.; Syverud, K.; Mustafa, K. Coating 3D printed polycaprolactone scaffolds with nanocellulose promotes growth and differentiation of mesenchymal stem cells. Biomacromolecules 2018, 19, 4307-4319. [CrossRef]

110. Jin, L.; Xu, Q.; Kuddannaya, S.; Li, C.; Zhang, Y.; Wang, Z. Fabrication and characterization of three-dimensional (3D) core-shell structure nanofibers designed for 3D dynamic cell culture. ACS Appl. Mater. Interface 2017, 9, 17718-17726. [CrossRef]

111. Jin, L.; Xu, Q.; Wu, S.; Kuddannaya, S.; Li, C.; Huang, J.; Zhang, Y.; Wang, Z. Synergistic effects of conductive three-dimensional nanofibrous microenvironments and electrical stimulation on the viability and proliferation of mesenchymal stem cells. ACS Biomater. Sci. Eng. 2016, 2, 2042-2049. [CrossRef]

112. Chrzanowski, W.; Lee, J.H.; Kondyurin, A.; Lord, M.S.; Jang, J.H.; Kim, H.W.; Bilek, M.M. Nano-bio-chemical braille for cells: The regulation of stem cell responses using bi-functional surfaces. Adv. Funct. Mater. 2014, 25, 193-205. [CrossRef]

113. Fayol, D.; Frasca, G.; Le Visage, C.; Gazeau, F.; Luciani, N.; Wilhelm, C. Use of magnetic forces to promote stem cell aggregation during differentiation, and cartilage tissue modeling. Adv. Mater. 2013, 25, 2611-2616. [CrossRef]

114. Jin, L.; Hu, B.; Li, Z.; Li, J.; Gao, Y.; Wang, Z.; Hao, J. Synergistic effects of electrical stimulation and aligned nanofibrous microenvironment on growth behavior of mesenchymal stem cells. ACS Appl. Mater. Interfaces 2018, 10, 18543-18550. [CrossRef]

115. Moreau, J.; Xu, H. Mesenchymal stem cell proliferation and differentiation on an injectable calcium phosphate-Chitosan composite scaffold. Biomaterials 2009, 30, 2675-2682. [CrossRef]

116. Ragetly, G.R.; Griffon, D.J.; Lee, H.B.; Fredericks, L.P.; Gordon-Evans, W.; Chung, Y.S. Effect of chitosan scaffold microstructure on mesenchymal stem cell chondrogenesis. Acta Biomater. 2010, 6, 1430-1436. [CrossRef] [PubMed]

117. Bishi, D.K.; Mathapati, S.; Venugopal, J.R.; Guhathakurta, S.; Cherian, K.M.; Ramakrishna, S.; Verma, R.S. Trans-differentiation of human mesenchymal stem cells generates functional hepatospheres on poly(L-lactic acid)-co-poly(E-caprolactone)/collagen nanofibrous scaffolds. J. Mater. Chem. B 2013, 1, 3972-3984. [CrossRef]

118. Lee, J.H.; Park, J.H.; Yun, Y.R.; Jang, J.H.; Lee, E.J.; Chrzanowski, W.; Wall, I.B.; Kim, H.W. Tethering bi-functional protein onto mineralized polymer scaffolds to regulate mesenchymal stem cell behaviors for bone regeneration. J. Mater. Chem. B 2013, 1, 2731-2741. [CrossRef]

119. Meka, S.R.K.; Chacko, L.A.; Ravi, A.; Chatterjee, K.; Ananthanarayanan, V. Ananthanarayanan, Role of microtubules in osteogenic differentiation of mesenchymal stem cells on 3D nanofibrous scaffolds. ACS Biomater. Sci. Eng. 2017, 3, 551-559. [CrossRef]

120. Taskin, M.B.; Xu, R.; Gregersen, H.; Nygaard, J.V.; Besenbacher, F.; Chen, M. Three-dimensional polydopamine functionalized coiled microfibrous scaffolds enhance human mesenchymal stem cells colonization and mild myofibroblastic differentiation. ACS Appl Mater. Interfaces 2016, 8, 15864-15873. [CrossRef] [PubMed]

121. Hu, F.; Chen, T.; Wang, W. Effects of polyethylene oxide and poly(3-hydroxybutyrate-co-3-hydroxyvalerate) nanofibrous substrate on omental adipose-derived mesenchymal stem cell neuronal differentiation and peripheral nerve regeneration. RSC Adv. 2017, 7, 42833-42844. [CrossRef] 
122. Almeida, H.V.; Liu, Y.; Cunniffe, G.M.; Mulhall, K.J.; Matsiko, A.; Buckley, C.T.; O’Brien, F.J.; Kelly, D.J. Controlled release of transforming growth factor- $\beta 3$ from cartilage-extra-cellular-matrix-derived scaffolds to promote chondrogenesis of human-joint-tissue-derived stem cells. Acta Biomater. 2014, 10, 4400-4409. [CrossRef] [PubMed]

123. Meinel, L.; Karageorgiou, V.; Fajardo, R.; Snyder, B.; Shinde-Patil, V.; Zichner, L.; Kaplan, D.; Langer, R.; Vunjak-Novakovic, G. Bone tissue engineering using human mesenchymal stem cells: Effects of scaffold material and medium flow. Ann. Biomed. Eng. 2004, 32, 112-122. [CrossRef] [PubMed]

124. Gomes, M.E.; Sikavitsas, V.I.; Behravesh, E.; Reis, R.L.; Mikos, A.G. Effect of flow perfusion on the osteogenic differentiation of bone marrow stromal cells cultured on starch-based three-dimensional scaffolds. J. Biomed. Mater. Res. 2003, 67, 87-95. [CrossRef] [PubMed]

125. Orza, A.; Soritau, O.; Olenic, L.; Diudea, M.; Florea, A.; Rus Ciuca, D.; Mihu, C.; Casciano, D.; Biris, A.S. Electrically conductive gold-coated collagen nanofibers for placental-derived mesenchymal stem cells enhanced differentiation and proliferation. ACS Nano 2011, 5, 4490-4503. [CrossRef] [PubMed]

126. McCreedy, D.A.; Wilems, T.S.; Xu, H.; Butts, J.C.; Brown, C.R.; Smith, A.W.; Sakiyama-Elbert, S.E. Survival, differentiation, and migration of high-purity mouse embryonic stem cell-derived progenitor motor neurons in fibrin scaffolds after sub-acute spinal cord injury. Biomater. Sci. 2014, 2, 1672-1682. [CrossRef] [PubMed]

127. Ko, E.; Alberti, K.; Lee, J.S.; Yang, K.; Jin, Y.; Shin, J.; Yang, H.S.; Xu, Q.; Cho, S.W. Nanostructured tendon-derived scaffolds for enhanced bone regeneration by human adipose-derived stem cells. ACS Appl. Mater. Interfaces 2016, 8, 22819-22829. [CrossRef] [PubMed]

128. Tian, L.; Prabhakaran, M.P.; Hu, J.; Chen, M.; Besenbacher, F.; Ramakrishna, S. Coaxial electrospun poly(lactic acid)/silk fibroin nanofibers incorporated with nerve growth factor support the differentiation of neuronal stem cells. RSC Adv. 2015, 5, 49838-49848. [CrossRef]

129. Fan, L.; Liu, C.; Chen, X.; Zou, Y.; Zhou, Z.; Lin, C.; Tan, G.; Zhou, L.; Ning, C.; Wang, Q. Directing induced pluripotent stem cell derived neural stem cell fate with a three-dimensional biomimetic hydrogel for spinal cord injury repair. ACS Appl. Mater. Interfaces 2018, 10, 17742-17755. [CrossRef] [PubMed]

130. Neffe, A.T.; Pierce, B.F.; Tronci, G.; Ma, N.; Pittermann, E.; Gebauer, T.; Frank, O.; Schossig, M.; Xu, X.; Willie, B.M.; et al. One step creation of multifunctional 3D architectured hydrogels inducing bone regeneration. Adv. Mater. 2015, 27, 1738-1744. [CrossRef]

131. Khetan, S.; Guvendiren, M.; Legant, W.R.; Cohen, D.M.; Chen, C.S.; Burdick, J.A. Degradation-mediated cellular traction directs stem cell fate in covalently cross-linked three-dimensional hydrogels. Nat. Mater. 2013, 12, 458-465. [CrossRef]

132. Yang, C.; Tibbitt, M.W.; Basta, L.; Anseth, K.S. Mechanical memory and dosing influence stem cell fate. Nat. Mater. 2014, 13, 645-652. [CrossRef]

133. Li, N.; Zhang, Q.; Gao, S.; Song, Q.; Huang, R.; Wang, L.; Liu, L.; Dai, J.; Tang, M.; Cheng, G. Three-dimensional graphene foam as a biocompatible and conductive scaffold for neural stem cells. Sci. Rep. 2013, 3, 1-6. [CrossRef]

134. Yamashita, Y.I.; Shimada, M.; Tsujita, E.; Tanaka, S.; Ijima, H.; Nakazawa, K.; Sakiyama, R.; Fukuda, J.; Ueda, T.; Funatsu, K.; et al. Polyurethane foam/spheroid culture system using human hepatoblastoma cell line (Hep G2) as a possible new hybrid artificial liver. Cell Transplant. 2001, 10, 717-722. [CrossRef]

135. Hardy, J.G.; Sukhavasi, R.C.; Aguilar, D.; Villancio-Wolter, M.K.; Mouser, D.J.; Geissler, S.A.; Nguy, L.; Chow, J.K.; Kaplan, D.L.; Schmidt, C.E. Electrical stimulation of human mesenchymal stem cells on biomineralized conducting polymers enhances their differentiation towards osteogenic outcomes. J. Mater. Chem. B 2015, 3, 8059-8064. [CrossRef]

136. Hardy, J.G.; Villancio-Wolter, M.K.; Sukhavasi, R.C.; Mouser, D.J.; Aguilar, D., Jr.; Geissler, S.A.; Kaplan, D.L.; Schmidt, C.E. Electrical stimulation of human mesenchymal stem cells on conductive nanofibers enhances their differentiation toward osteogenic outcomes. Macromol. Rapid Commun. 2015, 36, 1884-1890. [CrossRef] [PubMed]

137. Hardy, J.G.; Geissler, S.A.; Aguilar, D., Jr.; Villancio-Wolter, M.K.; Mouser, D.J.; Sukhavasi, R.C.; Cornelison, R.C.; Tien, L.W.; Preda, R.C.; Hayden, R.S.; et al. Instructive conductive 3D silk foam-based bone tissue scaffolds enable electrical stimulation of stem cells for enhanced osteogenic differentiation. Macromol. Biosci. 2015, 15, 1490-1496. [CrossRef] [PubMed] 
138. Lee, D.; Choi, K.S.; Kim, D.; Park, S.; Kim, W.; Jang, K.J.; Lim, K.T.; Chung, J.H.; Seonwoo, H.; Kim, J. Iron oxide nanoparticle-incorporated alginate capsules as magnetic field-assisted potential delivery platforms for agriculture pesticides and biocontrol agents. J. Biosyst. Eng. 2017, 42, 323-329.

139. Kim, D.G.; Seo, S.W.; Cho, B.K.; Lohumi, S.; Hong, S.J.; Lee, W.H. Review of current approaches for implementing metabolic reconstruction. J. Biosyst. Eng. 2018, 43, 45-58.

140. Seo, Y.R.; Kim, J.W.; Hoon, S.; Kim, J.; Chung, J.H.; Lim, K.T. Cellulose-based nanocrystals: Sources and applications via agricultural byproducts. J. Biosyst. Eng. 2018, 43, 59-71.

141. Wang, M.O.; Piard, C.M.; Melchiorri, A.; Dreher, M.L.; Fisher, J.P. Evaluating changes in structure and cytotoxicity during in vitro degradation of three-dimensional printed scaffolds. Tissue Eng. Part A 2015, 21, 1642-1653. [CrossRef] [PubMed]

142. Chieruzzi, M.; Pagano, S.; Lombardo, G.; Marinucci, L.; Kenny, J.M.; Torre, L.; Cianetti, S. Effect of nanohydroxyapatite, antibiotic, and mucosal defensive agent on the mechanical and thermal properties of glass ionomer cements for special needs patients. J. Mater. Res. 2018, 33, 638-649. [CrossRef]

143. Vishwakarma, A.; Bhise, N.S.; Evangelista, M.B.; Rouwkema, J.; Dokmeci, M.R.; Ghaemmaghami, A.M.; Vrana, N.E.; Khademhosseini, A. Engineering immunomodulatory biomaterials to tune the inflammatory response. Trends Biotechnol. 2016, 34, 470-482. [CrossRef]

144. Singh, A.; Peppas, N. Hydrogels and scaffolds for immunomodulation. Adv. Mater. 2014, 26, 6530-6541. [CrossRef]

145. Taraballi, F.; Sushnitha, M.; Tsao, C.; Bauza, G.; Liverani, C.; Shi, A.; Tasciotti, E. Biomimetic tissue engineering, tuning the immune and inflammatory response to implantable biomaterials. Adv. Health Care Mater. 2018, 7, 1800490. [CrossRef] [PubMed]

146. Lebbink, R.J.; de Ruiter, T.; Adelmeijer, J.; Brenkman, A.B.; van Helvoort, J.M.; Koch, M.; Farndale, R.W.; Lisman, T.; Sonnenberg, A.; Lenting, P.J.; et al. Collagens are functional, high affinity ligands for the inhibitory immune receptor LAIR-1. J. Exp. Med. 2006, 203, 1419-1425. [CrossRef] [PubMed]

147. Lebbink, R.J.; Raynal, N.; de Ruiter, T.; Bihan, D.G.; Farndale, R.W.; Meyaard, L. Identification of multiple potent binding sites for human leukocyte associated Ig-like receptor LAIR on collagens II and III. Matrix Biol. 2009, 28, 202-210. [CrossRef] [PubMed]

148. Donaldson, A.R.; Tanase, C.E.; Awuah, D.; Bathrinarayanan, P.V.; Hall, L.; Nikkhah, M.; Khademhosseini, A.; Rose, F.; Alexander, C.; Ghaemmaghami, A.M. Photocrosslinkable gelatin hydrogels modulate the production of the major pro-inflammatory cytokine, TNF- $\alpha$, by Human Mononuclear Cells. Front. Bioeng. Biotechnol. 2018, 6, 116. [CrossRef] [PubMed]

149. Cha, B.H.; Shin, S.R.; Leijten, J.; Li, Y.C.; Singh, S.; Liu, J.C.; Annabi, N.; Abdi, R.; Dokmeci, M.R.; Vrana, N.E.; et al. Integrin-mediated interactions control macrophage polarization in 3D hydrogels. Adv. Healthcare Mater. 2017, 6, 1700289. [CrossRef]

150. Rowley, A.T.; Nagalla, R.R.; Wang, S.W.; Liu, W.F. Extracellular matrix-based strategies for immunomodulatory biomaterials engineering. Adv. Healthcare Mater. 2019, 8, 1801578. [CrossRef]

151. Price, R.D.; Myers, S.; Leigh, I.M.; Navsaria, H.A. The Role of Hyaluronic Acid in Wound Healing. Am. J. Clin. Dermatol. 2005, 6, 393-402. [CrossRef]

152. Wrobel, M.; Sundararaghavan, H. Biomaterial Cues to Direct a Pro-regenerative Phenotype in Macrophages and Schwann Cells. Neuroscience 2018, 376, 172-187. [CrossRef]

153. Laurence, A.; Tato, C.M.; Davidson, T.S.; Kanno, Y.; Chen, Z.; Yao, Z.; Blank, R.B.; Meylan, F.; Siegel, R.; Hennighausen, L.; et al. Interleukin-2 Signaling via STAT5 Constrains T Helper 17 Cell Generation. Immunity 2007, 26, 371-381. [CrossRef]

154. Banchereau, J.; Pascual, V.; O'garra, A. From IL-2 to IL-37: The expanding spectrum of anti-inflammatory cytokines. Nat. Immunol. 2012, 13, 925-931. [CrossRef]

155. Brown, B.N.; Valentin, J.E.; Stewart-Akers, A.M.; McCabe, G.P.; Badylak, S.F. Macrophage phenotype and remodeling outcomes in response to biologic scaffolds with and without a cellular component. Biomaterials 2009, 30, 1482-1491. [CrossRef] [PubMed]

156. Sicari, B.M.; Dziki, J.L.; Siu, B.F.; Medberry, C.J.; Dearth, C.L.; Badylak, S.F. The promotion of a constructive macrophage phenotype by solubilized extracellular matrix. Biomaterials 2014, 35, 8605-8612. [CrossRef] [PubMed]

157. Wong, M.L.; Wong, J.L.; Vapniarsky, N.; Griffiths, L.G. In vivo xenogeneic scaffold fate is determined by residual antigenicity and extracellular matrix preservation. Biomaterials 2016, 92, 1-12. [CrossRef] [PubMed] 
158. Meng, F.W.; Slivka, P.F.; Dearth, C.L.; Badylak, S.F. Solubilized extracellular matrix from brain and urinary bladder elicits distinct functional and phenotypic responses in macrophages. Biomaterials 2015, 46, 131-140. [CrossRef] [PubMed]

159. Dziki, J.L.; Wang, D.S.; Pineda, C.; Sicari, B.M.; Rausch, T.; Badylak, S.F. Solubilized extracellular matrix bioscaffolds derived from diverse source tissues differentially influence macrophage phenotype. J. Biomed. Mater. Res. Part A 2016, 105, 138-147. [CrossRef] [PubMed]

160. Lynn, A.D.; Kyriakides, T.R.; Bryant, S.J. Characterization of thein vitromacrophage response andin vivohost response to poly(ethylene glycol)-based hydrogels. J. Biomed. Mater. Res. Part A 2009, 93, 941-953. [CrossRef] [PubMed]

161. Zaveri, T.D.; Lewis, J.S.; Dolgova, N.V.; Clare-Salzler, M.J.; Keselowsky, B.G. Integrin-directed modulation of macrophage responses to biomaterials. Biomaterials 2014, 35, 3504-3515. [CrossRef] [PubMed]

162. Lynn, A.; Bryant, S. Phenotypic changes in bone marrow-derived murine macrophages cultured on PEG-based hydrogels activated or not by lipopolysaccharide. Acta Biomater. 2011, 7, 123-132. [CrossRef] [PubMed]

163. Manicone, A.; Mcguire, J. Matrix metalloproteinases as modulators of inflammation. Semin. Cell Dev. Biol. 2008, 19, 34-41. [CrossRef]

164. Westermann, D.; Savvatis, K.; Schultheiss, H.P.; Tschöpe, C. Immunomodulation and matrix metalloproteinases in viral myocarditis. J. Mol. Cell. Cardiol. 2010, 48, 468-473. [CrossRef] [PubMed]

165. Churg, A.; Wang, R.D.; Tai, H.; Wang, X.; Xie, C.; Dai, J.; Shapiro, S.D.; Wright, J.L. Macrophage metalloelastase mediates acute cigarette smoke-induced inflammation via tumor necrosis factor- $\alpha$ release. Am. J. Respir. Crit. Care Med. 2003, 167, 1083-1089. [CrossRef] [PubMed]

166. Haro, H.; Crawford, H.C.; Fingleton, B.; Shinomiya, K.; Spengler, D.M.; Matrisian, L.M. Matrix metalloproteinase-7-dependent release of tumor necrosis factor- $\alpha$ in a model of herniated disc resorption. J. Clin. Investig. 2000, 105, 143-150. [CrossRef] [PubMed]

(C) 2019 by the authors. Licensee MDPI, Basel, Switzerland. This article is an open access article distributed under the terms and conditions of the Creative Commons Attribution (CC BY) license (http://creativecommons.org/licenses/by/4.0/). 